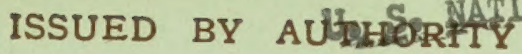
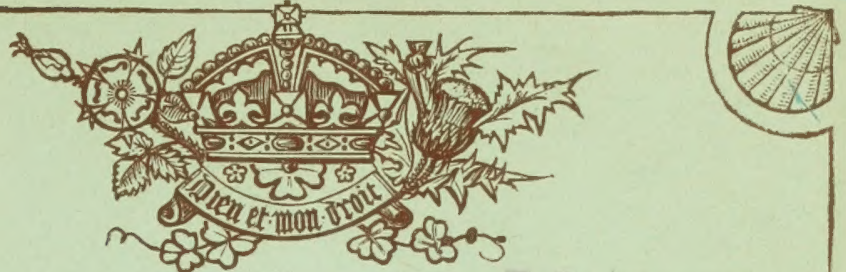

PAPERS OF THE CONFERENCES

Held in connection with

The GREAT JTERTEATONCA FISHERIES EXHIBITION

\title{
LINE FISHING
}

w

C. M. MUNDAHL 



\section{M96International Fisheries Exhibition}

$$
\text { L O N DON, I } 883
$$

\section{LINE FISHING}

BY

C. M. MUNDAHL

\section{LONDON}

WILLIAM CLOWES AND SONS, Limited INTERNATIONAL FISHERIES EXHIBITION

AND 13 CHARING CROSS, S.W. 



\section{International Fisheries Exhibition. LONDON, 1883 .}

Conference on Tuesday, June $26,1883$.

Mr. Edward Heneage, M.P., occuipied the chair.

\section{I N E F IS H I N G.}

By the courtesy of the promoters of this Exhibition I have been requested to read a paper on the subject of Line Fishing.

Whatever may be the imperfection of my remarks on the subject, I venture to speak to you as one who has for many years past paid some attention to the subject, and who has had a considerable range of experience, not only within the fishing grounds of the North Sea, but beyond the North Cape of Norway, on the great fishery of Finmarken, and the various other fisheries of that coast, and in another direction on those of Iceland and the Faroe Islands.

In order to avoid trespassing on the patience of my audience I have curtailed my remarks as much as possible. Very much more might be said, but then I do not claim that my paper will be exhaustive.

Line-fishing refers to the capture of fish by line and hook. It is divided into two systems :-Ist, Long-line fishing, which implies a continuous length of line with hooks attached on smaller lines of about three feet length at 
intervals of about ten feet. Such a line may extend for a distance of several miles, and have upon it 5,000 or 6,000 hooks. It is secured on the ground by an anchor at each end and at intervals of about every half a mile. From the point of each of these anchors a buoy-line rises to the surface of the sea, where it is attached to a buoy. The buoy carries a flag from a staff about ten feet in height, and may be seen for a distance of two or three miles.

Hand-lining is the term used for a single line with a lead attached in order to sink it to the bottom, and from this lead two short lines, with a hook on each, are suspended. Such a line is worked by a man or boy from the vessel's deck, and as many as ten or twelve may be worked at the same time on each of the larger vessels, which are known as codmen.

Fishing by means of lines and hooks has been carried on for many centuries; mention is made of it in the Book of Isaiah, etc., but the subject of its antiquity has been treated at length in the elaborate paper read by the learned Professor at the inauguration of this series of Conferences, and it remains for me to deal with its practice in our own day.

So far as explorers have penetrated into regions far removed from the limits of civilization, wherever these are bordered by the ocean, they have found implements corresponding to our hooks and lines, and have furnished accounts which show that a considerable portion of the food supply of the untaught savage is obtained by the hook and line. Very interesting specimens of the crude fishing gear of the Esquimaux are exhibited in the United States section of this Exhibition; the hook is formed of two pieces of bone and the line is made of strips of sealskin, and although the hook is not furnished with the barb invari- 
ably found on the fish-hook of civilized people, yet I can well conceive that it is possible, where fish is plentiful, to procure a sufficiency even with a hook so clumsy.

While referring to this fact, it may be not uninteresting to notice the wide distance between civilized and uncivilized life denoted by the barb of the fish-hook. Probably centuries of use and observation lay between the first hook and the hook which by an advance of thought was furnished with a barb.

Line-fishing is carried on to a greater or less extent all round the coasts of the United Kingdom, but the most important fishing ground is found in the North Sea, and it is from this ocean that by far the larger quantity is brought to our markets.

Not only is Great Britain supplied from the rich harvest which these waters yield, but all the countries bordering on the North Sea draw their fish supply from the same locality, and carry on considerable commerce in the various kinds of fish.

Taking into account the area of the North Sea, and the number of people supplied with food from it, as well as the great variety of fish found therein, it may be regarded as the most important fishing ground in the world. Taking a line eastward from the Shetland Isles and continuing southward to the North Foreland, from shore to shore, whether on its shallows or in its depths, on its even grounds or in its caverns - which the fishermen call pits, or holes-fish of some kind or other is found in greater or less quantity. The variety consists of cod, ling, haddock, halibut, coalfish, whiting, skate: these are the principal kinds caught on line, while almost every other kind which supplies the table of rich or poor is caught in the trawl or in the drift-net. 
The other large grounds are the Bank of Newfoundland, the great fisheries of Lofoden and Finmarken on the coast of Norway, and Iceland and the Faroe Islands.

So far as information can be gathered on the question, it appears that as early as the beginning of the present century the English and Scotch were already taking the greatest advantage of the fisheries of the North Sea ; the Dutch were the only other people who prosecuted deep sea fishing to any extent, but these, although holding a prominent position in the line fishery of the North Sea, and notwithstanding that their method of fishing is of the very best, yet in the number and tonnage of their vessels, or in the number of men employed, they have been left far behind in the race of competition.

The French have only within the last ten years made their appearance as line-fishers in the North Sea; on the other hand they prosecute on a large scale the fisheries of Newfoundland and those of Iceland, the latter of which I shall take occasion to refer to before I conclude.

Belgium sends a few vessels to the hand-line fishing in the North Sea, but these vessels are small and inferior, and do not compare with the craft of either England or Holland engaged in the same trade. They fish for cod, most of which is salted in barrels for home consumption, and in this particular branch they certainly succeed in producing a very superior quality.

Holland, as already remarked, takes a prominent part in the line-fishing of the North Sea. Besides having a fleet of several hundred open boats and vessels of small size, which fish with lines along shore when circumstances permit, they have a fleet of some fifty vessels or more sailing from the fishing ports of Perniss, Middleharniss, Zwartewaal, Raardingen and Maasluis. 
Nearly the whole of this fleet consists of vessels of a modern class, which have supplanted the old Dutch hooker of primitive shape, with its great square sail. They are constructed with wells for the keeping of the fish alive, and generally during the summer months carry ice, with which they preserve the dead fish of their cargo. They bring about one-half of their winter's catch to the English market, making Grimsby their rendezvous; another considerable portion of the catch is disposed of in Belgium.

During the summer months a number of this fleet is occupied in the herring fishery, another part in the haddock fishery, and the remainder in the hand-line fishery for cod in the northern latitudes of the North Sea. At this season of the year, instead of keeping their catch alive, they salt it in barrels and land it at Vlaardingen, which is the great Dutch market for this article. From this place it is distributed, partly to other Dutch markets, but chiefly to Belgium.

Germany does not put in an appearance at all on the high seas. I am aware that small fleets of fishing boats sail from Blankensee, principally, and from other points down to Cuxhaven on the Elbe, and a few from the rivers Weser and Jahde, but they seldom venture beyond Heligoland Deep, and indeed few of them, if any, come within the branch of line-fishing.

It is a matter of surprise, and one that may be worthy the notice of His Excellency the German Ambassador, who appears to take an active interest in the present Exhibition, that so great a nation as Germany, and a people so energetic in all commercial life, should prefer to go abroad for a considerable portion of their fish supply, when they might profitably occupy in the trade a considerable number of 
the population, and by such means become their own purveyors.

Denmark finds a supply of fish along the shores of Jutland, in the Kattegat and the Belts; their line-fishing is confined to these waters, and is prosecuted with vessels of small tonnage and by open boats. They make no attempts to supply other nations, and on the other hand they do not need to purchase to any great extent from abroad.

Sweden sends a large fleet of fishing vessels to the linefishing in the North Sea. Their vessels are not attractive in appearance; having a keel short in proportion to the length over all, they present a rather unsightly picture, but are constructed with a view of riding at anchor in the open sea. They are probably the best model for such a purpose.

They are usually manned with twelve hands. The vessels are mostly laid up during the winter months from November to March, and for the rest of the year they are occupied principally in long-line fishing between the latitudes of $57^{\circ}$ and $63^{\circ} \mathrm{N}$. They carry on their operations along the edge of the great bank which runs along the deep-water channel fronting the Norwegian coast, and is commonly known as the Reef; but several of them have of late years moved westwardly to within fifty miles of the north of Scotland.

Their practice is to place their lines on sloping ground, from a less to a greater depth of the sea, sometimes to as much as 200 fathoms, a depth so considerable that almost all other fishermen shrink from the severe labour entailed in hauling them in again. The hardy Swede, however, appears to take it all as a matter of course, and is frequently rewarded for his toil by immense catches of ling and other kinds of fish. 
I am informed on reliable authority that as many as a thousand ling have been taken in one day; reckoning a ling at an average of 24 lbs. this represents nearly $\mathrm{IO}_{2}^{1}$ tons of ling, besides cod and other kinds of fish, of which they catch a fair proportion. These quantities are perhaps not equalled by any fishermen in the North Sea, and can only be approached in their quantity by the Norwegian fishermen at the great periodical fisheries of Lofoden, Finmarken, and Romsdal.

The bait used by the Swedish fishermen is in the first instance the mussel. With these they bait their haddock line, which they work on banks adjacent to their great fishing grounds, where the haddock is found in large quantities; after a day's catch of haddock they sail away into deeper waters, and then in its turn the shiny haddock is cut up to make bait for the ling and cod, so carrying out the great law of the survival of the fittest.

A specialty of the Swedish fishing lines is the float used on the snood. This is made of cedar bark cut to shape, about three inches long by one inch in diameter, and boiled in beeswax in order to render it impervious to water; it is so attached with respect to the hook as to keep the latter about two feet from the ground. Like the swinging signboard of a country inn, it makes a display which the hungry traveller cannot well resist, and as a consequence it is readily snapped at. It also serves the purpose of keeping the bait off the dirty ground and above the reach of the star-fish and creeping insects which infest large portions of the bottom of the sea.

The position held by Norwegian fisheries is by far the most important both as regards the number of persons employed and the quantities landed. But inasmuch as their great fisheries are localised and carried on within 
the limits of their own coasts, and as they have been already referred to by Professor Huxley, I will only briefly notice them.

Their boats are almost exclusively open, and of a small size compared with the usual fishing vessel for the open sea. Their lines and hooks are about the same as those used by our own smacks, the principle of working them is also nearly the same, with this exception, that whereas the immense shoals of cod on their journey to the coast do not always take the ground-as the term is -but move at a greater or less depth, they ascertain the position of the fish in the sea, and then instead of sinking their line to the bottom they suspend it in midwater by means of glass globes which they attach to their line. Specimens of these glass globes may be seen in the splendid collection of the Norwegian department. I am not aware that this system is used by any other fishermen, but it recommends itself as a very ingenious and successful method, and as a proof of its utility I may remark that instances have come under my notice in which on a line of 3000 hooks, so suspended, 2000 fish have been taken in one haul, while neighbouring boats whose lines have been set at a greater depth have drawn almost a blank.

Some attempts have been made of late years by the Norwegians to take a part in the open sea fisheries, and I regret to say they have not been so successful as they deserve. I venture, however, to express the opinion that as a people they possess too much energy and enterprise to be baffled by a few fruitless attempts, and that by perseverance they will succeed. A people so hardy, and by constant practice so inured to the hardships and dangers of the sea, is eminently qualified to take a prominent position in this direction. Having so far 
briefly considered the position of our friends and neighbours as regards the subject of my address I will pass on to notice our home line-fishing.

I have already referred to the fact that line-fishing is carried on more or less all round our coast. There is scarcely a village or a hamlet on the east coast of England and Scotland without its fishermen. The beach boat, yawl, coble and other open boats that venture out from along the English and Scotch coasts when weather and other circumstances permit, to work their lines, may be counted by hundreds. But, as His Royal Highness the Duke of Edinburgh has remarked in his admirable paper, "the term fisherman is a somewhat elastic one," and the occupations of persons who style themselves fishermen are of such varied character that we must leave these in order to deal with that class whose sole occupation is fishing and who make this calling the business of their life.

Before the railway system had grown to anything like its present proportion the small town of Barking in Essex was the great fishing centre of England. Being near to London and on the Thames its situation was a most convenient one for the fishermen who made it their business to supply the Metropolis with fish. Nearly fifty years ago a fleet of about 200 decked vessels sailed from this place, and the trade was considerably developed as regards the size and construction of their vessels and the efficiency of the men themselves. Still their smacks were small compared with those of the present day; most of them were under forty tons register. These vessels were adapted both for lining and trawling, and were alternately occupied in each trade. The remainder of the lining flect was made up from Greenwich, Harwich, Gravesend, Aldborough, Blackwall and Deptford. They used to go to the Dogser Bank during the winter months, and worked with lons-lines; during the 
summer months some of them fished with hand-lines on the north coast of Scotland, some of them were occupied in carrying lobsters from Norway and Sweden to the London market, and others were engaged in the whiting and haddock fishing. They all used to bring their live cargoes to Gravesend and thence sent them forward from day to day to Billingsgate market.

In the year 1851 the Manchester, Sheffield and Lincolnshire Railway Company had completed their magnificent new docks and line at Grimsby ; and the direct connection established by this rail with London and the great provincial centres, together with the geographical position of the port with regard to the great fishing banks, recommonded it as the most convenient fishing centre on the east coast.

Smack owners from Harwich, Greenwich and Barking commenced to send their vessels here periodically; a company in connection with the Manchester, Sheffield, and Lincolnshire Railway Company was formed, and for some years employed twelve smacks-one half the number in the lining, and the other half in the trawling business. A market and a dock for the special use of the fish trade were constructed in 1855 ; and so rapid has been the growth of the trade from that time to the present day that the efforts of the railway company in extending the dock accommodation have hardly been able to keep pace with the increasing trade.

I have not been able strictly to arrive at the relative figures of tonnage, but I shall not be far from the fact, and perhaps near enough for the purpose of this paper, if I compute the tonnage of all fishing vessels in Grimsby in $1 S_{55}$ at $S 00$ tons, half of which were cod smacks. At present the tonnage actually belonging to the port is not far short of 40,000 , Sooo tons of which is represented by about $120 \mathrm{cod}$ 
smacks, while most of the cod vessels from Greenwich, Harwich, and also from Holland, trade here regularly during the long-line season. The population of Grimsby has during the same period increased from 10,000 to about 40,000.

This great development of the line-fishing at Grimsby has not been without its effect on the other fishing torns which I have named. Barking and some of the other places referred to have retired from the trade altogether, and Greenwich and Harwich are now the only other places from which cod vessels take part in the line-fishing, and that only to a small extent.

A number of yawls or luggers from Filey, Scarborough, Hartlepool, and the Tyne, engage in decp sea lining cluring the spring of the year, but they are not vessels with wells, and can only be said to be partly engaged in the trade.

A cod smack is a fore-and-aft dandy rigged vessel, with foremast and mizen-mast. Those built of late years vary from seventy to eighty-five tons, and we have some of over 120 tons register. The usual dimensions are sixtyfive to seventy feet length of keel, twenty to twenty-one feet beam, and eleven feet to eleven feet six inches depth amidships; in ordinary ballast trim they draw about eleven feet of water aft, and from seven to seven and a half feet forward. They are as a rule fast sailers, and their seagoing qualitics cannot be surpassed. I make no doubt that Christopher Columbus and Captain Cook would have rejoiced to have had such vessels for their expeditions. They are built principally of oak, and fitted with cabin and forcastle; the master and five men occupy the cabin, and four to six boys the forecastle.

In the centre of the vessel a space of nearly one third of the length of the keel is set apart for the well; this is divided off by strong bulkheads, or well-heads as they are 
termed, of oak twelve to fourteen inches thick; the space so set apart is again divided by one or two sectional bulkheads, thus forming two or three wells, as the case may be. These well-heads are carried upwards for about half the cntire height of the vessel, or about five feet six inches, a strong oak deck is then laid over all from the fore to the aft well-head, forming what in a merchant ship would be called 'tween decks, and on board smacks is styled a well deck. From the centre of the well deck a strongly encased watertight hatchway called a well funnel rises to the upper deck. The bottom of the well is planked over in the same way as the rest of the vessel outside, in the planks well-holes are bored about fifteen inches apart, and through these the water is admitted into the well, and by the motion of the vessel when at sea is freely circulated. Above the well deck and in the after part of the vessel's hold, the space is used for an ice room, where about eight tons of ice is stowed, and compartments made for the stowage of the fish which die on the voyage. The fore part of the vessel's hold is used for spare sails and the fishing gear. The smack carries with it a boat about twenty feet in length, six feet four inches in width, and three feet in depth. Very frequently this boat is used for hauling the lines at sea, and when the winter gales carry destruction to the ships in the North Sea, the English fisherman is never slow in launching his boat and risking his own life in order to save his fellow. Never a winter goes by without numerous instances of this kind taking place, in many cases without reward or even notice being bestowed, in others they are duly acknowledged.

The bait formerly used by the codmen was whelks, but for the last twelve years this has been varied with lampreys and herrings, when obtainable, according to the season of 
the year, and the fishing grounds where their operations have been carried on. During the summer months, whelks and herrings are now used, and from October to April, lampreys and whelles by the vessels that go to the Dogroer and the Great Fishery Banks, but whelks only by the vessels that fish on the grounds nearer home.

The cost of bait is a considerable item in the outfit of a cod smack, amounting to from twelve to twenty pounds per voyage. Ice is another item, which may be put as from seven pounds to ten pounds per voyage, and these, together with wages and food for the crew, harbour dues and other requirements, bring the current expenses of a smack up to about thirty pounds weekly, without any allowance for wear and tear, insurance or interest on capital invested.

The vessels are insured in local mutual insurance societies against total and partial loss up to a sum representing from one half to two-thirds of their value, and the yearly cost of assurance seldom exceeds two and a half per cent. of amount assured. A smack such as I have described of about eighty tons register costs ready for sea from $£ \mathrm{I}, 600$ to $£ \mathrm{I}, 800$.

Previous to I 862 the long-line operations never extended beyond the Dogger Bank. But since then they have year after year been carried further northerly and easterly, and at the present time the whole area from Shetland southwards is fished upon.

As soon as the vessel arrives on the fishing ground, the lines are got ready, and the hooks baited. Where whelks are used as bait, the shells are broken with a mallet, the snail is sorted out, and carefully put on the hook. If lamprey or herrings are used, they are cut into small slices and so put on the hook. A curious fact with regard to this kind of bait is, that cod, haddock, or ling will seldom 
or ever accept the tail-picce of either lamprey or herring. The skate however is not so particular with regard to the joint.

The lines are coiled into a tray made of wood, usually 480 fathoms in each, and the hooks are placed with careful regularity in rows on the bottom of the tray. About two or three hours before sunrise the lines are laid out. The end of the line is attached to an anchor, which is secured to a buoy-line and buoy, the vessel is steered away, usually to the wind or close hauled, and one of the men "pays out" or "shoots" the line, as it is termed, while the rest attend to the anchors and buoys. When the whole length of line is out, it is allowed to remain two or three hours, and then the hauling commences. As soon as a cod or ling is caught it is carefully pierced under the fin on the right side, in order that the air with which the belly of the fish is inflated may escape. This operation, which is carricd out in less time than I have used to relate it, being performed, the fish is dropped into the well. The cod and haddock are usually allowed to swim about free, the ling and halibut are suspended by their tails, and so confined they are found to live longer.

A day's catch may vary from twenty cod or even less, to three or four hundred cod and ling, and proportionate quantities of haddock and other fish. The vessel usually returns to port after an absence of from eight to twenty days; on its arrival the live fish are put into chests or trunks, which are kept afloat in the dock and adapted so that the water may circulate freely from without. The dead fish are landed in the market, and it is sold at once, being forwarded thence to all parts of England, Scotland, and even to Ireland.

During the summer months the greater number of the 
vessels go to the codfishing at Iceland and the Faroe Islands, where they fish with hand-lines. The fish caught here is salted during the first part of the voyage, and the fish so salted is generally sold to merchants in Shetland, who dry it and export it to the Spanish, Scotch, and Irish markets. During the latter part of this voyage they keep the best of their catch alive, and bring this proportion home at the close of their voyage.

I mentioned in the early part of my remarks that the French sent a considerable flect to the Iceland fishery, and I wish to draw attention to the fact that the French Government send with this fishing flect a corvette and a gunboat, whose duty it is to superintend and assist, and give prestige to their fishermen in those parts. Considering the number of British lives and the amount of British property employed in the same direction I venture to think that if our Government could be induced to send one of their smaller vessels of war to this coast during the fishing season it would be an act of service to British interests.

There is only one other point to which I beg to call your attention. On the nearest banks and along the shore of the east coast a large quantity of immature cod are caught, and I firmly believe, notwithstanding what we have heard from Professor Huxley on the subject, that this wholesale capture of the young will sooner or later affect our supply of cod on the home grounds.

My proposal is, that a law similar to that which protects the crab and the lobster should extend to all kinds of immature fish so far as it is possible to carry it out, and as the Board of Trade is very anxious to do something for the fishing trade, I would very respectfully suggest that it should take the young fish under its care, and establish one or 
more stations for the culture of those kinds of sea-fish which form such important part of the food supply of the nation.

\section{DISCUSSION.}

Sir Edvard WATKin proposed a vote of thanks to $\mathrm{Mr}$. Mundahl for his very able paper. He said he did not do so as a mere matter of compliment, but because the paper rcally contained a great deal of instruction and information on a most interesting question. With regard to one of his remarks as to the course which the French Government had taken with regard to protecting and keeping order on the fishing grounds where French vessels were occupied, he must say that he had often wondered, seeing that Englishmen were more dependent on fishing than any other country, that our Government should have taken so little care to protect and keep order on the fishing grounds where our fishermen were employed. He could only explain the reason of the apparent indifference which was shown, by the fact that in many public departments the people who had to do the executive work were excessively ignorant. $\mathrm{He}$ did not know whether any one else present had been struck with it, and perhaps it would be rather out of order for him to make such a remark, but in this country we seemed to be getting every day more and more infested by those ignorant people who were always anxious to get official pay and employment. He had no doubt now that Mr. Mundahl had called attention to this matter, and that, generally speaking, owing to this Exhibition, public attention was being concentrated on the important question of our fisheries, there would be a little more courtesy and attention shown on the part of the Government, and that 
encouragement which the flag of England always gave would be afforded to those industrious men who risked their lives in an important and interesting calling, and that it would be found that some of our gunboats would be placed on important fishing grounds as a regular institution of the future. Mr. Mundahl had explained in the most graphic and interesting language the whole operation of line fishing, and no doubt there were many things which would be eminently suggestive to those who had listened to the paper. He had certainly taught him a great deal ; and no doubt every one, although they might be acquainted with the subject, would learn something. It was not always, even in these interesting discussions, that everything useful was to be learned, and nothing which had a contrary tendency; he did not know whether it was the fault of the reporters, but he read the other day in the Times that at one of the previous Conferences it was laid down as a fact that the fishermen were a class of persons so very improvident and so very poor that they were always in debt. Whether that was so in other parts of the country he could not say, but with regard to the two great fishing districts he had been acquainted with, viz., Great Yarmouth and Grimsby, he did not think there was a more provident, saving, and God-fearing class all round than the fishermen of those two places, and he decidedly objected to its being put forward that they were so improvident that all the year round they must be in debt. Again, they were told on cminent authority that these men ought to put their money into saving banks and things of that kind, and ought never to enter into speculation by putting their money into the fishing industry with which they were connected. Now, his opinion was that the man who was connected with any industry which he liked, which he conducted with success, 
and which was the occupation of his life, could not do better than invest his savings in that industry. He was afraid that he had rather digressed from the first line of proposing a vote of thanks to Mr. Mundahl, but he could not help making these observations. The Chairman, the Hon. Member for Grimsby, and himself, with a number of others, were members of a Select Committee to consider the question of harbours, and that day before coming to the meeting he put a question to Mr. Stephenson, one of the most eminent of the Scotch engineers who built the harbours and lighthouses round the coast of Scotland, saying they had been told by Sir Thomas Boyd that since the improvement of the harbours of Scotland during the last forty years the fishing trade had doubled, and further that if they could only provide proper harbours round the Scotch coast the extcnsion of the fishing industry was illimitable, and asked Mr. Stephenson his opinion upon it. His reply was, "Well, illimitable is a large word, but I do not think it is extreme. I think the whole question of the extension of fisheries in Scotland is a question of the improvement of harbours." Now, if that were so they knew exactly what was required, and he was quite certain that in that Committec they would have the candid support of the Honourable Members for Grimsby in favour of improving the harbours of England, Scotland, and Ireland as far and as fast as they could, with the view of improving this noble industry of fishing. There was only one other point he wished to mention, and that was this-it was not merely a question of catching fish, it was a question of the naval supremacy of this country, for if the fishing interest were abolished to-day where would be the navy the day after; if on the other hand by a judicious outlay of capital, everybody pulling together, and dropping all that 
nonsense about private enterprise, they could bring the force of opinion to bear in favour of the construction of great public works all round the coast, they would not only be securing a large increase of the fishing industry, but would also be increasing the supply of that grand human raw material which would defend our coasts against any enemy, and secure for ever the supremacy of England on the sea.

Mr. BiRkiecK, M.P., had great pleasure in seconding the motion. It was most gratifying to the Executive Committee that they had been so fortunate in the selection of the gentleman who had just read the paper on this very important industry, and felt sure that when the ultimate result of the Exhibition was collected, as he hoped it would be in a very formidable blue book, this paperwould appear in it, and prove of very great interest. Personally he took great interest in this question, because from his boyhood upwards he had been over these very grounds to which Mr. Mundahl had referred, and perhaps even further; he had been up as far as Spitzbergen and seen shark fishing there. One of the most amusing incidents in connection with that fishing was this. When the smachs about the size Mr. Mundahl had referred to had commenced their fishing, sport was very bad for the first few days, because they had to get rid of the smaller sharks, and, rather than throw them overboard and let them sink down for the larger sharks to feed upon, they adopted the very ingenious plan of taking out their livers, introducing a pair of bellows, and, sewing up the shark's belly, let the fish float away with the tide, so that the larger sharks they wanted to catch would rot prey on the smaller ones. He felt confident when this question of line fisheries was more prominently brought before the country that the application of capital to far more distant grounds would follow, and in that way the supply of fish would be 
largely increased. He begged to thank Mr. Mundahl on behalf of the Committee for his most excellent paper.

The Chairman, in putting the vote of thanks, said he naturally took the very greatest interest in the paper, not only for its own value, but on account of the gentleman who had read it, for being so essentially connected with Grimsby, everything to do with fishing and those engaged in it must have the deepest interest for him. He could not attempt to compete with the gentlemen who had already spoken in their knowledge of this subject. Sir Edward Watkin had, perhaps, in railway enterprise done more for fishing than any man living, the proof of which was shown by the statement given in the paper of the position of Grimsby with regard to fishing some twenty or thirty years ago compared with what it was now. If any further proof were required he would recommend any one to read the very excellent report of the Committee which sat last year on the condition of fishing lads and others engaged in the trade in England and Scotland. He entirely agreed with what had fallen from Sir Edward Watkin and Mr. Mundahl with regard to the way in which the fishing interest was neglected by public departments. He thought it was a disgrace that we had not with our large fleets a man-of-war or gunboat always at hand, not only to be a protection to boats when fishing, but also to be there ready to give assistance when those sudden squalls or gales came on which had done so much to make wiclows and orphans during the last two or three years. If a gunboat or a man-of-war had been on the spot in March last they would not now have been required to raise a large fund for the widows and orphans of Hull and Grimsby, which he regretted to say they were obliged to do now ; at the same time he hoped that all would generously contribute to the relicf of that which was almost a national 
calamity. With regard to what had been said by a learned gentleman in one of the previous papers as to the improvident character of fishermen, he ventured to say that facts entirely contradicted the statement. The matter came before him when working with the Board of Trade Committee, that a very large proportion indeed of those who entered as apprentices or seamen into this work rose to be some of the largest smack owners in England, and that being so, it could not be said that there was such great improvidence. They knew that in all classes there was improvidence, but why this fault should be charged upon fishermen in particular he had never been able to understand.

Earl Ducie then moved a vote of thanks to the Chairman.

Mr. Mundahl said it afforded him very great pleasure to second the resolution. As a Grimsby man who had the honour of being represented by Mr. Heneage, it always gave him, as it did a large proportion of the Grimsby people, great pleasure to meet Mr. Heneage, because he was always so ready and willing to do anything he could for the benefit either of the fishing interest or the general interests of the town. Before sitting down he would take the liberty of saying, in response to the vote of thanks which had been passed, that the requests of the energetic and able Chairman of the Exhibition were always made with such geniality and courtesy that it afforded every one great pleasure at all times to comply with them. Personally he felt indebted to Mr. Birkbeck for the part he had taken in arranging this Exhibition. He had the greatest hope as to the fruits of it, and he was sure the nation would forget itself if it did not in some substantial way recognise the services of Mr. Birkbeck.

(The vote of thanks was carried unanimously, and briefly acknowledged by the Chairman.) 
LONDON :

PRINTED BY WILLIAM CLOWES AND SONS, Limited, STAMFORD STREET AND CHARING CROSS. 
Microformed by

Presorvation

Services

$$
\operatorname{mim} \# \frac{5081.09}{3.22 .94}
$$




\section{OFFICIAL PU]}

P.

The following Handbooks upon subjects cognate to the International Fisheries Exhibition are already published, or in active preparation:-

Demy 8vo., in Illustrated Wrapper, price Is, each.

FISHERY LAWS. By FrederICK Pollock, Barrister-at-Law, M.A. (Oxon.), Hon. LL.D. Edin., Corpus Christi Professor of Jurisprudence in the University of Oxford.

ZOOLOGY AND FOOD FISHES. By GeORGE B. Howes, Demonstrator of Biology, Normal School of Science, and Royal School of Mines, South Kensington.

THE HISTORY OF FISHING FROIM THE EARLIEST TIMES. By W. M. AdAMs, M.A. (Oxon.), late Fellow of New College.

MARINE AND FRESHWATER FISHES OF THE BRITISH ISLANDS. (Illusirated.) By W. SAVILlE KENT, F.L.S., F.Z.S., Author of Official Guidebooks to the Brighton, Manchester, and Westminster Aquaria.

THE BRITISH FISH TRADE. By His Excellency SPENCER WALPOLE, Lieut.-Governor of the Isle of Man.

FISH CULTURE. (Illustrated.) By Francis Day, F.L.S., Commissioner for India to International Fisheries Exhibition.

APPARATUS FOR FISHING. By E. W. H. Holdsworth, F.L.S., F.Z.S., Special Commissioner for Juries, International Fisheries Exhibition; Author of "Deep Sea Fisheries and Fishing Boals," "British Industries-Sea Fisheries," \&c.

FISh AS DIET. By W. Stephen Mitchell, M.A. (Cantab.)

ANGLING IN GREAT BRITAIN. By William Senior ("Red Spinner").

EDIBLE CRUSTACEA. By W. Saville Kent, F.L.S., F.Z.S., Author of Official Guidebooks to the Brighton, Manchester, and Westminster Aquaria.

THE UNAPPRECIATED LIFE OF THE BRITISH FISHERMAN. By JAMES G. BERTHAM, Author of "The Harvest of the Sea."

THE SALIMON FISHERIES. (Illustrated.) By C. E. FRYER. Assistant Inspector of Salmon Fisheries, Home Office.

THE ANGLING SOCIETIES OF LONDON AND THE PROVINCES. By J. P. WHEELDON, late Angling Editor of "Bell's Life."

INDIAN FISH AND FISHING. (Illustrated.) By FRANCIS DAY, F.L.S., Commissioner for India to International Fisheries Exhibition.

SEA MONSTERS UNIMASKED. (Illustrated.) By HENRY LEE, F.L.S.

THE LITERATURE OF SEA AND RIVER FISHING. By John J. MANLey, M.A. (Oxon.)

THE OUTCOIME OF THE EXHIBITION. By A. J. R. TRENDELL, of the Inner Temple, Barrister-at-Law, Literary Superintendent for the Fisheries Exhibition.

\section{LONDON :}

WILLIAM CLOWES AND SONS, LIMITED, INTERNATIONAL FISHERIES EXHIBITION, \& I3, CHARING CROSS. 